Vol 12, Issue 6, 2019

\title{
HELICHRYSUM PETIOLARE HILLIARD AND B. L. BURTT: A REVIEW OF ITS MEDICINAL USES, PHYTOCHEMISTRY, AND BIOLOGICAL ACTIVITIES
}

\author{
ALFRED MAROYI* \\ Department of Botany, Medicinal Plants and Economic Development Research Centre, University of Fort Hare, Private Bag X1314, \\ Alice 5700, South Africa. Email: amaroyi@ufh.ac.za
}

Received: 04 April 2019, Revised and Accepted: 07 May 2019

\begin{abstract}
Helichrysum petiolare is a valuable and well-known medicinal herb in South Africa. A comprehensive review of phytochemical, medicinal uses, and biological activities of $H$. petiolare is presented in this study. Information on biological activities, medicinal uses, and phytochemistry of $H$. petiolare was gathered from several internet sources which included Scopus, Google Scholar, Elsevier, Science Direct, Web of Science, PubMed, SciFinder, and BMC. Additional information on these aspects was sourced from pre-electronic sources such as journal articles, scientific reports, theses, books, and book chapters obtained from the University library. The current study revealed that $H$. petiolare is mainly used as herbal medicine for respiratory infections, diabetes, fever, headache, heart problem, high blood pressure, pain, reproductive problems, and wounds. Phytochemical studies showed that H. petiolare extracts and compounds isolated from the species have antifungal, anti-inflammatory, antibacterial, antioxidant, antityrosinase, antigenotoxicity, and cytotoxicity activities. This research showed that $H$. petiolare is an integral part of indigenous pharmacopeia in South Africa, but there is the lack of alignment between the known medicinal applications, phytochemistry, and biological activities of the species. Therefore, future research should focus on evaluating the chemical and pharmacological properties of $H$. petiolare extracts and compounds associated with the species.
\end{abstract}

Keywords: Asteraceae, Helichrysum petiolare, Ethnopharmacology, Herbal medicine, Southern Africa.

(c) 2019 The Authors. Published by Innovare Academic Sciences Pvt Ltd. This is an open access article under the CC BY license (http://creativecommons. org/licenses/by/4. 0/) DOI: http://dx.doi.org/10.22159/ajpcr.2019.v12i6.33417

\section{INTRODUCTION}

Helichrysum petiolare Hilliard and B. L. Burtt is a small shrub which is a member of the Asteraceae or Compositae family. The species is endemic to South Africa, confined to the Free State, Western Cape, Eastern Cape, and Northern Cape Provinces [1-6]. The species is commonly known by several vernacular names which include the following: Bedding Helichrysum, cudweed everlasting, herbal Helichrysum and silver bush everlasting (English), hottentotskooigoed, hottentotskruie, kooigoed, and kruie (Afrikaans), and imphepho (Xhosa) [7-11]. A single synonym "Helichrysum petiolatum auct. non (L.) DC." was found in literature [1-5]. The genus name "Helichrysum" is based on the Greek word "helios" which translates to "sun" and "chrysos" which translates to "gold," in reference to "golden flowers" which are characteristic of the genus [11]. The species name, "petiolare" is in reference to long leaf stalks which are a characteristic feature of the species $H$. petiolare [11]. The height of $H$. petiolare ranges from 30 to $120 \mathrm{~cm}$, has been recorded in drier inland sheltered slopes in the fynbos biome, transition zones, and forest margins at an altitude ranging from 120 to $1420 \mathrm{~m}$ above sea level [1-6,11]. $H$. petiolare is a perennial scrambling or trailing shrub with dense, aromatic, roundish to ovate, green-yellowish leaves covered by silver-gray hairs $[2,11]$. The inflorescence is made up of many tiny yellow flowers forming small flower heads, surrounded by creamy white and papery floral bracts on long stalks. The seeds of $H$. petiolare are small, lightweight, with tuft of bristly hairs at one end and are dispersed by wind [11].

H. petiolare is an important ornamental plant in Namibia, South Africa, North Africa, Europe, and the United States of America [11-21]. The species is attractive and has been sold in specialty nurseries as an ornamental plant throughout the world [12]. H. petiolare is now listed as a weed in the global collection of weeds by Randall [22] and Mouriño et al. [23] described the species as an invasive species in Spain, invading natural and semi-natural habitats as well as managed afforested areas and maritime protected areas. In the USA, $H$. petiolare is listed as an invasive weed, invading coastal scrubland and conifer forests [24]. Based on literature records, $H$. petiolare is naturalized as a casual or invasive weed in France, North Africa, New Zealand, Portugal, Spain, Sweden, the UK, and the USA [13,14,20,23,25-30]. The species was first recorded as naturalized in the Iberian Peninsula in Portugal in 1943 [30] and by 1952, the species was widespread in Portugal as a weed, established in natural or semi-natural communities [31]. H. petiolare was introduced in the USA as an ornamental herb [12] and escaped from cultivation in areas like California around $1960[12,24,32,33]$. The current study is focusing on the medicinal applications of the species and its contribution to primary health care of local communities. Therefore, the current study is aimed at providing a comprehensive review of ethnomedicinal value, phytochemistry, and biological activities of compounds isolated from the species, including $H$. petiolare crude extracts.

\section{MEDICINAL USES OF H. PETIOLARE}

Research by Oliver [11] showed that $H$. petiolare is one of the best known and commonly used herbal medicines in South Africa. Similarly, Van Wyk et al. [34] listed H. petiolare as one of the popular Helichrysum species used as herbal medicines against menstrual pain, colds, coughs, infections, headache, and fever in South Africa. Other Helichrysum species with medicinal applications similar to those of $H$. petiolare are Helichrysum aureonitens Sch. Bip., Helichrysum nudifolium (L.) Less., Helichrysum odoratissimum (L.) Sweet, Helichrysum pedunculatum Hilliard and B. L. Burtt, and H. cymosum (L.) D. Don [35-60]. Research by Loundou [61] revealed that leaves and stems of $H$. petiolare are sold in the informal herbal medicines markets of the Eastern Cape and Western Cape Provinces of South Africa as herbal medicines. The leaves, twigs, whole plant parts, or sometimes roots are used as herbal medicines for mainly respiratory infections, diabetes, fever, headache, heart problem, high blood pressure, pain, reproductive problems, and wounds as indicated in Table 1.

\section{BIOLOGICAL ACTIVITIES}

H. petiolare contain a diversity of terpenoids and non-terpenoids (Table 2) that have been identified from the flowers, leaves, and twigs of the species $[63,69-71]$. The major compounds that have been identified 
Table 1: Medicinal uses of $H$. petiolare in South Africa

\begin{tabular}{lll}
\hline Disease & Parts used & References \\
\hline Antiseptic & Leaves & {$[11,62]$} \\
Asthma & Leaves & {$[10,11,63]$} \\
Catarrh & Leaves & {$[62,64]$} \\
Chest problems & Leaves & {$[10,11,63]$} \\
Colds & Leaves & {$[11,62-64]$} \\
Cough & Leaves & {$[11,62-64]$} \\
Diabetes & Whole plant & {$[65-68]$} \\
Fever & Whole plant & {$[62,64]$} \\
Headache & Whole plant & {$[62,64]$} \\
Heart problems & Whole plant & {$[17]$} \\
High blood pressure & Leaves & {$[10,11,63]$} \\
Infections & Leaves & {$[10,11]$} \\
Insect repellent against & Leaves mixed with those of & {$[11]$} \\
flies and mosquitos & Artemisia afra Jacq. ex Willd & \\
Menstrual problems & Whole plant & {$[62,64]$} \\
Respiratory problems & Leaves & {$[10]$} \\
Pain & Leaves & {$[11,63]$} \\
Urinary tract infections & Whole plant & {$[62,64]$} \\
Wounds & Leaves & {$[10,11,62,64]$} \\
\hline
\end{tabular}

H. petiolare: Helichrysum petiolare from the species include $\beta$-bisabolene (19.5-25.6\%), $\alpha$-bulnesene (19.5-25.6\%), caryophyllenyl alcohol (36.4-45.3\%), 1,8-cineole $(<0.01-22.4 \%), \quad \beta$-hydroagarofuran $\quad(19.5-25.6 \%), \quad$ and $\beta$-pinene $(<0.01-51.3 \%)[63,69,70]$.

\section{BIOLOGICAL ACTIVITIES}

The following biological activities have been reported from $H$. petiolare crude extracts and essential oils extracted from the species: Antibacterial $[62,69,70,72]$, antifungal [62], antioxidant [69], antityrosinase [73], anti-inflammatory [69], antigenotoxicity [74], and cytotoxicity [72] activities.

\section{Antibacterial activities}

Lourens et al. [69] evaluated antibacterial activities of acetone and methanol leaf extracts and essential oils of $H$. petiolare against Staphylococcus aureus, Escherichia coli, Bacillus cereus, Bacillus subtilis, Yersinia enterocolitica, and Klebsiella pneumoniae using disc diffusion assay and microtiter plate dilution method with neomycin (30 $\mu \mathrm{g} / \mathrm{disc}$ ) as the positive control. The acetone and methanol extracts exhibited activities against $S$. aureus and B. cereus with zone of inhibition ranging from $2.5 \mathrm{~mm}$ to $9.0 \mathrm{~mm}$, while the essential oil was

Table 2: Phytochemical composition of $H$. petiolare

\begin{tabular}{|c|c|c|c|}
\hline Phytochemical composition (\%) & Values & Plant parts & References \\
\hline Ar-curcumene & 0.6 & Leaves & [69] \\
\hline Allo-aromadendrene & $0.6-0.8$ & Flowers, leaves, and twigs & [63] \\
\hline Aromadendrene & 0.3 & Aerial parts and leaves & {$[69,70]$} \\
\hline$\alpha$-trans-Bergamotene & 0.2 & Flowers & [63] \\
\hline$\beta$-Bisabolene & $19.5-25.6$ & Flowers, leaves, and twigs & [63] \\
\hline$\alpha$-Bisabolol & 0.3 & Flowers, leaves, and twigs & [63] \\
\hline epi- $\alpha$-Bisabolol & 0.2 & Flowers, leaves, and twigs & [63] \\
\hline Borneol & $<0.1-3.3$ & Flowers, leaves, and twigs & {$[63,69,70]$} \\
\hline Bornyl acetate & $<0.1-0.5$ & Flowers, leaves, and twigs & [63] \\
\hline$\alpha$-Bulnesene & $19.5-25.6$ & Flowers, leaves, and twigs & [63] \\
\hline Cubenol & 0.3 & Flowers, leaves, and twigs & [63] \\
\hline Cadalene & $0.2-0.3$ & Flowers, leaves, and twigs & [63] \\
\hline trans-Cadina-1,4-diene (Cubebene) & $<0.1$ & Flowers, leaves, and twigs & [63] \\
\hline$\alpha$-Cadinene & $<0.01$ & Flowers, leaves, and twigs & [63] \\
\hline$\delta$-Cadinene & $0.7-4.8$ & Aerial parts, flowers, leaves, and twigs & {$[63,69,70]$} \\
\hline$\alpha$-Cadinol & 0.2 & Aerial parts and leaves & {$[69,70]$} \\
\hline T-Cadinol & 0.2 & Aerial parts and leaves & {$[69,70]$} \\
\hline$\alpha$-Calacorene & $0.1-1.6$ & Aerial parts, flowers, leaves, and twigs & {$[63,69,70]$} \\
\hline Cis-calamenene & 0.3 & Leaves & [69] \\
\hline Calamenene & 0.3 & Aerial parts & {$[70]$} \\
\hline Camphene & $<0.01-0.4$ & Aerial parts, flowers, leaves, and twigs & {$[63,69,70]$} \\
\hline$\alpha$-Campholenal & 0.1 & Flowers, leaves, and twigs & [63] \\
\hline Camphor & $0.1-1.9$ & Aerial parts, flowers, leaves, and twigs & {$[63,69,70]$} \\
\hline Carotol & $0.1-1.1$ & Flowers, leaves, and twigs & [63] \\
\hline Carvacrol & 0.1 & Aerial parts and leaves & {$[69,70]$} \\
\hline trans-Carveol & 0.1 & Aerial parts and leaves & {$[69,70]$} \\
\hline Caryophylladienol II & $0.2-0.4$ & Aerial parts and leaves & {$[69,70]$} \\
\hline Caryophyllenyl alcohol & $36.4-45.3$ & Flowers, leaves, and twigs & [63] \\
\hline$\beta$-Caryophyllene alcohol & 1.9 & Aerial parts and leaves & {$[69,70]$} \\
\hline Caryophyllene oxide & $0.1-2.5$ & Aerial parts, flowers, leaves, and twigs & {$[63,69,70]$} \\
\hline$\beta$-Caryophyllene & $0.3-14.0$ & Aerial parts, flowers, leaves, and twigs & {$[63,69-71]$} \\
\hline 1,8-Cineole & $<0.01-22.4$ & Aerial parts, flowers, leaves, and twigs & {$[63,69,70]$} \\
\hline Clovenol & 0.1 & Aerial parts and leaves & {$[69,70]$} \\
\hline$\alpha$-Copaene & $0.1-2.4$ & Aerial parts, flowers, and leaves & {$[63,69,70]$} \\
\hline$\beta$-Copaene & $0.2-0.4$ & Flowers, leaves, and twigs & [63] \\
\hline 1-epi-Cubenol & $0.8-1.2$ & Flowers, leaves, and twigs & [63] \\
\hline ar-Curcumene & $0.6-0.7$ & Aerial parts, flowers, leaves, and twigs & {$[63,70]$} \\
\hline p-Cymen-8-ol & 0.3 & Aerial parts and leaves & {$[69,70]$} \\
\hline Cyperene & 0.2 & Flowers, leaves, and twigs & [63] \\
\hline
\end{tabular}


Table 2: (Continued)

\begin{tabular}{|c|c|c|c|}
\hline o-Cymene & $<0.01-1.0$ & Flowers, leaves, and twigs & [63] \\
\hline p-Cymene & 9.8 & Aerial parts and leaves & {$[69,70]$} \\
\hline p-Cymenene $=\alpha$, & 0.1 & Aerial parts & [70] \\
\hline p-Dimethylstyrene & & & \\
\hline Decanal & $<0.1-1.4$ & Flowers, leaves, and twigs & {$[63]$} \\
\hline (E)-2-Decenal & $<0.1$ & Flowers, leaves, and twigs & [63] \\
\hline 1,10-Di-epi-cubenol & $0.1-0.2$ & Flowers, leaves, and twigs & [63] \\
\hline$\alpha, p$-Dimethylstyrene & 0.1 & Leaves & [69] \\
\hline cis-1,2-Epoxy-terpin-4-ol & 0.4 & Aerial parts and leaves & {$[69,70]$} \\
\hline 10-epi-y-Eudesmol & $0.9-1.3$ & Flowers, leaves, and twigs & [63] \\
\hline$\alpha$-Fenchone & $<0.01-0.7$ & Aerial parts and leaves & {$[69,70]$} \\
\hline Fenchyl alcohol & 1.5 & Aerial parts and leaves & {$[69,70]$} \\
\hline Geranyl acetate & $0.1-0.4$ & Aerial parts and leaves & {$[69,70]$} \\
\hline (E)-Geranyl acetate & 0.1 & Aerial parts and leaves & {$[69,70]$} \\
\hline Germacrene D-4-ol & $<0.1-2.3$ & Flowers, leaves, and twigs & [63] \\
\hline Gleenol & $<0.1$ & Flowers, leaves, and twigs & [63] \\
\hline Globulol & 0.2 & Aerial parts and leaves & {$[69,70]$} \\
\hline 3,7-Guaiadiene & $0.1-0.6$ & Aerial parts and leaves & {$[69,70]$} \\
\hline Guaiol & $<0.1-2.0$ & Flowers, leaves, and twigs & [63] \\
\hline$\alpha$-Gurjunene & $<0.01-0.5$ & Aerial parts, flowers, leaves, and twigs & {$[63,69,70]$} \\
\hline$\gamma$-Gurjunene & 0.1 & Aerial parts and leaves & {$[69,70]$} \\
\hline 1-Heptanol & 0.1 & Aerial parts & [70] \\
\hline 1-Hexanol & $<0.01$ & Aerial parts & {$[70]$} \\
\hline Hexyl valerate & $<0.01$ & Aerial parts & [70] \\
\hline Humulene epoxide I & 0.1 & Aerial parts and leaves & {$[69,70]$} \\
\hline Humulene epoxide II & $0.1-1.4$ & Aerial parts, flowers, leaves, and twigs & {$[63,69,70]$} \\
\hline$\alpha$-Humulene & $2.0-3.8$ & Aerial parts, flowers, leaves, and twigs & {$[63,69,70]$} \\
\hline$\beta$-Hydroagarofuran & $19.5-25.6$ & Flowers, leaves, and twigs & [63] \\
\hline Intermedeol & $0.3-3.3$ & Flowers, leaves, and twigs & [63] \\
\hline Isocaryophyllene oxide & 0.6 & Aerial parts and leaves & {$[69,70]$} \\
\hline Isoitalicene & 0.1 & Aerial parts and leaves & {$[69,70]$} \\
\hline Italicene & 1.0 & Aerial parts and leaves & {$[69,70]$} \\
\hline Kaur-15-ene & 0.3 & Aerial parts and leaves & {$[69,70]$} \\
\hline Kaur-16-ene & 1.3 & Aerial parts & {$[70]$} \\
\hline Lavandulyl isobutyrate & $0.2-0.4$ & Flowers, leaves, and twigs & [63] \\
\hline Lavandulyl isovalerate & $1.9-2.5$ & Flowers, leaves, and twigs & {$[63]$} \\
\hline Ledol & 0.2 & Aerial parts and leaves & {$[69,70]$} \\
\hline Limonene & $<0.01-5.2$ & Aerial parts, flowers, leaves, and twigs & {$[63,69,70]$} \\
\hline Linalool & $<0.1-0.4$ & Flowers, leaves, and twigs & [63] \\
\hline Longiborneol (=juniperol) & 0.3 & Flowers, leaves, and twigs & {$[63]$} \\
\hline (E)- $\beta$-Ionone & 0.6 & Flowers, leaves, and twigs & [63] \\
\hline 6-Methyl-5-hepten-2-one & $<0.01$ & Aerial parts and leaves & {$[69,70]$} \\
\hline$\alpha$-Muurolene & 2.2 & Leaves & [69] \\
\hline$\alpha$-Muurolol & $0.1-0.4$ & Flowers, leaves, and twigs & [63] \\
\hline$\gamma$-Muurolene & $<0.01-2.2$ & Aerial parts, flowers, leaves, and twigs & {$[63,69,70]$} \\
\hline Myrcene & $0.2-0.7$ & Aerial parts, flowers, leaves, and twigs & {$[63,69,70]$} \\
\hline trans-Myrtanol acetate & $<0.1-0.2$ & Flowers, leaves, and twigs & [63] \\
\hline Myrtenal & $0.2-0.3$ & Flowers, leaves, and twigs & [63] \\
\hline Myrtenyl acetate & $0.4-0.8$ & Flowers, leaves, and twigs & {$[69,70]$} \\
\hline (E)-Nerolidol & 0.1 & Aerial parts and leaves & {$[69,70]$} \\
\hline Neryl valerate & 0.3 & Aerial parts and leaves & {$[69,70]$} \\
\hline (E)-2-Nonenal & $<0.1$ & Flowers, leaves, and twigs & [63] \\
\hline Nonanal & 0.3 & Flowers, leaves, and twigs & [63] \\
\hline$(Z)-\beta$-Ocimene & $<0.01-0.3$ & Aerial parts, flowers, leaves, and twigs & {$[63,69,70]$} \\
\hline$(E)-\beta$-Ocimene & $<0.01$ & Aerial parts, flowers, leaves, and twigs & {$[63,69,70]$} \\
\hline 1-Octen-3-ol & 0.1 & Aerial parts and leaves & {$[69,70]$} \\
\hline Palustrol & 0.3 & Aerial parts and leaves & {$[69,70]$} \\
\hline Patchouli alcohol & 4.0 & Flowers & [63] \\
\hline$\alpha$-Pinene & $0.1-8.7$ & Aerial parts, flowers, leaves, and twigs & {$[63,69,70]$} \\
\hline$\alpha$-Pinene oxide & $<0.01$ & Aerial parts & [70] \\
\hline$\beta$-Pinene & $<0.01-51.3$ & Aerial parts, flowers, leaves, and twigs & {$[63,69,70]$} \\
\hline cis-Pinocamphone & $<0.01-0.3$ & Flowers, leaves, and twigs & [63] \\
\hline trans-Pinocarvyl acetate & $0.1-0.2$ & Flowers, leaves, and twigs & [63] \\
\hline trans-Pinocarveol & $<0.01-0.4$ & Aerial parts, flowers, leaves, and twigs & {$[63,69,70]$} \\
\hline Pinocarvone & $<0.1$ & Flowers, leaves, and twigs & [63] \\
\hline cis-Sabinene hydrate & $<0.01$ & Flowers, leaves, and twigs & {$[63]$} \\
\hline Safranal & 0.1 & Flowers, leaves, and twigs & [63] \\
\hline$\beta$-Selinene & 0.6 & Flowers, leaves, and twigs & {$[63]$} \\
\hline
\end{tabular}


Table 2: (Continued)

\begin{tabular}{|c|c|c|c|}
\hline Selina-3,7-(11)-diene & 0.6 & Aerial parts and leaves & {$[70]$} \\
\hline Spathulenol & $0.2-2.4$ & Aerial parts, flowers, leaves, and twigs & {$[63,69,70]$} \\
\hline$\alpha$-Terpinene & $<0.01-3.1$ & Aerial parts, flowers, leaves, and twigs & {$[63,69,70]$} \\
\hline$\gamma$-Terpinene & $1.0-1.7$ & Aerial parts, flowers, leaves, and twigs & {$[63,69,70]$} \\
\hline 4-Terpineol & $<0.01-0.3$ & Flowers, leaves, and twigs & [63] \\
\hline$\alpha$-Terpineol & $<0.01-5.1$ & Aerial parts, flowers, leaves, and twigs & {$[63,69,70]$} \\
\hline$\delta$-Terpineol & $<0.01$ & Aerial parts and leaves & {$[69,70]$} \\
\hline Terpinolene & $<0.01-0.8$ & Aerial parts, flowers, leaves, and twigs & {$[63,69,70]$} \\
\hline 3-Thujanol & 0.2 & Flowers, leaves, and twigs & [63] \\
\hline Thymol methyl ether & 0.6 & Aerial parts and leaves & {$[69,70]$} \\
\hline Tricyclene & 0.2 & Flowers & [63] \\
\hline Undecanal & 0.1 & Flowers, leaves, and twigs & [63] \\
\hline Valencene & 0.2 & Flowers, leaves, and twigs & [63] \\
\hline Valeranone & $0.1-2.6$ & Flowers, leaves, and twigs & [63] \\
\hline Viridiflorol & $0.7-0.9$ & Aerial parts, flowers, leaves, and twigs & {$[63,69,70]$} \\
\hline
\end{tabular}

H. petiolare: Helichrysum petiolare

active against $S$. aureus with zone of inhibition of $<1.0 \mathrm{~mm}$ which was lower than $6.0 \mathrm{~mm}$ exhibited by the control. The minimum inhibitory concentration (MIC) values of acetone and methanol extracts against $S$. aureus and B. cereus ranged from $312.5 \mu \mathrm{g} / \mathrm{ml}$ to $625 \mu \mathrm{g} / \mathrm{ml}$, while MIC value of the essential oil against $S$. aureus was $8000 \mu \mathrm{g} / \mathrm{ml}$ which was much higher than MIC values of $0.08-0.31 \mu \mathrm{g} / \mathrm{ml}$ exhibited by the control [69]. Scott et al. [62] evaluated the antibacterial activities of the aqueous leaf extracts of $H$. petiolare against $S$. aureus, Pseudomonas aeruginosa, and Mycobacterium smegmatis using the disc diffusion assay with ciprofloxacin $(50 \mathrm{mg} / \mathrm{ml})$ as a positive control. The extracts exhibited activities against the tested pathogens with zone of inhibition ranging from $9 \mathrm{~mm}$ to $15 \mathrm{~mm}$ while ciprofloxacin, the positive control exhibited zone of inhibition ranging from $27 \mathrm{~mm}$ to $55 \mathrm{~mm}$ [62]. Reddy [70] evaluated antibacterial activities of acetone and methanol extracts of aerial parts of $H$. petiolare as well as essential oils isolated from the species against E. coli, Y. enterocolitica, Klebsiella pneumoniae, $S$. aureus, and B. cereus using disc diffusion assay with ciprofloxacin $(0.01 \mathrm{mg} / \mathrm{ml})$ as a positive control. The extract exhibited activities against $S$. aureus with MIC values ranging from $<0.25 \mathrm{mg} / \mathrm{ml}$ to $8.0 \mathrm{mg} / \mathrm{ml} \mathrm{[70].} \mathrm{Similarly,} \mathrm{Lourens} \mathrm{et} \mathrm{al.} \mathrm{[72]} \mathrm{evaluated} \mathrm{antibacterial}$ activities of chloroform:methanol (1:1) leaf and stem extracts of H. petiolare against $S$. aureus, Staphylococcus epidermidis, B. cereus, $K$. pneumoniae, and $P$. aeruginosa using the 96-well microplate method with ciprofloxacin as the positive control. The extracts exhibited activities against B. cereus with MIC value of $4.0 \mathrm{mg} / \mathrm{ml}$ [72].

\section{Antifungal activities}

Scott et al. [62] evaluated the antifungal activities of the aqueous leaf extracts of $H$. petiolare against Candida albicans using the disc diffusion assay with amphotericin $(25 \mathrm{mg} / \mathrm{ml})$ as a positive control. The extracts exhibited activities against the tested pathogen with zone of inhibition of $9.0 \mathrm{~mm}$ which was comparable to zone of inhibition of $15.0 \mathrm{~mm}$ exhibited by amphotericin, the positive control [62].

\section{Antioxidant activities}

Lourens et al. [69] evaluated the antioxidant activities of acetone and methanol leaf extracts and essential oils of $H$. petiolare using the 2,2-dipheny-l-picrylhydrazyl (DPPH) free radical scavenging assay with ascorbic acid as a reference drug. The extracts showed good DPPH activities with ethanol and methanol extracts exhibiting half maximal inhibitory concentration $\left(\mathrm{IC}_{50}\right.$ ) values of $44.3 \mu \mathrm{g} / \mathrm{ml}$ and $28.7 \mu \mathrm{g} / \mathrm{ml}$, respectively, while the control exhibited $\mathrm{IC}_{50}$ value of $2.5 \mu \mathrm{g} / \mathrm{ml}$ [69].

\section{Antityrosinase activities}

Sonka [73] evaluated antityrosinase activities of aerial part crude extracts of $H$. petiolare using a tyrosinase assay with kojic acid as a positive control. The extract showed significant effects on tyrosinase with inhibition rate of $44.3 \%$ at $50 \mu \mathrm{g} / \mathrm{ml}$ and $59.2 \%$ at $200 \mu \mathrm{g} / \mathrm{ml}$ [73]. This study gives some validation toward the use of the species as an antiseptic $[11,62]$ and for the treatment of infections $[10,11]$.

\section{Anti-inflammatory activities}

Lourens et al. [69] evaluated the anti-inflammatory activities of acetone and methanol leaf extracts and essential oils of $H$. petiolare using the 5-lipoxygenase assay with nordihydroguaiaretic acid as a positive control. The essential oil exhibited activities with $\mathrm{IC}_{50}$ value of $25.0 \mu \mathrm{g} / \mathrm{ml}$ while the positive control exhibited $\mathrm{IC}_{50}$ value of $5.0 \mu \mathrm{g} / \mathrm{ml}$ [69].

\section{Antigenotoxicity activities}

Makhuvele et al. [74] evaluated the genotoxicity and antigenotoxicity activities of dichloromethane and $90 \%$ methanol leaf extracts of H. petiolare against aflatoxin B1-induced mutagenicity using the Ames (Salmonella typhimurium strains TA98 and TA100) and Vitotox assays in the presence of 59 rat liver fraction. The extracts exhibited moderate to strong antimutagenic activities in both Ames and Vitotox assays [74]. Such plant extracts with promising antimutagenic effects could be used in the form of feed and food supplements as a preventative strategy against aflatoxin B1-induced mutagenicity and carcinogenicity.

\section{Cytotoxicity activities}

Lourens et al. [72] evaluated in vitro cytotoxicity activities of chloroform:methanol (1:1) leaf and stem extracts of $H$. petiolare against transformed human kidney epithelial (Graham) cells, MCF-7 breast adenocarcinoma, and SF-268 glioblastoma cells at a concentration of $0.1 \mathrm{mg} / \mathrm{ml}$ using the sulforhodamine B assay. The extract exhibited Graham cell growth ranging from $33.4 \%$ to $76.6 \%$ at the tested concentration [72], implying that the species may be toxic against Graham cells.

\section{CONCLUSION}

The diverse medicinal applications of $H$. petiolare and the scientific evidence of its biological activities indicate its potential as herbal medicine. There is a need for advanced phytochemical analyses and pharmacological evaluation of the crude extracts as well as compounds isolated from the species aimed at aligning the known medicinal applications of the species with its phytochemistry and pharmacological properties. There is a need for evaluation of the clinical significance of the antioxidant properties, cytotoxicity and toxicity using in vivo models.

\section{AUTHOR'S CONTRIBUTIONS}

The author declares that this work was done by the author named in this article.

\section{CONFLICTS OF INTEREST}

The author declares that he has no conflicts of interest.

\section{ACKNOWLEDGMENTS}

I would like to express my gratitude to the National Research Foundation, South Africa and Govan Mbeki Research and Development 
Centre, University of Fort Hare, for financial support to conduct this study.

\section{REFERENCES}

1. Hilliard OM. Compositae in Natal. Pietermaritzburg: University of Natal Press; 1977.

2. Hilliard OM. Gnaphaliinae. In: Leistner OA, editor. Flora of Southern Africa: Asteraceae. Pretoria: National Botanical Institute; 1983. p. 1-325.

3. Fabian A, Germishuizen G. Wild Flowers of Northern South Africa. Vlaeburg: Fernwood Press; 1997.

4. Goldblatt P, Manning JC. Cape Plants: A Conspectus of the Cape Flora of South Africa. Cape Town: Strelitzia 9, National Botanical Institute; 2000.

5. Germishuizen G, Meyer NL. Plants of Southern Africa: An Annotated Checklist. Pretoria: Strelitzia 14, National Botanical Institute; 2003.

6. Vlok J, Schutte-Vlok AL. Plants of the Klein Karoo. Pretoria: Umdaus Press; 2010.

7. Eliovson S. South African Wild Flowers for the Garden: Bulbs, Annuals, Perennials, Succulents, Shrubs and Trees: How to Grow them, Identify them and Use them for Effect. Johannesburg: Howard Timmins; 1984.

8. Dyson A. Getting to know Kirstenbosch National Botanical Garden: Indigenous Healing Plants of the Herb and Fragrance Garden. Cape Town: National Botanical Institute; 1994

9. Nowick E. Historical Common Names of Great Plains Plants, with Scientific Names Index. Lincoln: Zea Books; 2015.

10. Gulumian M, Yahaya ES, Steenkamp V. African herbal remedies with antioxidant activity: A potential resource base for wound treatment. Evid Based Complement Altern Med 2018;2018:58.

11. Oliver R. Helichrysum petiolare Hilliard and B. L. Burtt; 2019. Available from: http://www.pza.sanbi.org/helichrysum-petiolare. [Last accessed on 2019 Mar 15].

12. Randall JM. Weed Alert! New Invasive Weeds in California. California: Symposium Proceedings of the California Exotic Pest Plant Council; 1997. p. 1-6.

13. Di Tomaso J. In: Brunel S, editor. Don't Plant a Pest Initiative. Mèze: Proceedings of the International Workshop Invasive Plants in Mediterranean Type Regions of the World; 2005. p. 118-22.

14. Thuiller W, Richardson DM, Pysek P, Midgley GF, Hughes GO, Rouget M. Niche-based modelling as a tool for predicting the risk of alien plant invasions at a global scale. Glob Change Biol 2005;11:2234-50.

15. Thomac C. Gardeners' World Magazine: 101 Ideas for Pots: Fool Proofrecipes for Rear-Round Colour. Wemding: BBC Books; 2007.

16. Ogden S, Ogden LS. Plant-Driven Design: Creating Gardens that Honorplants, Place, and Spirit. London: Timber Press; 2008

17. Van Jaarsveld E. Waterwise Gardening in South Africa and Namibia. Cape Town: Struik Lifestyle; 2010.

18. Welsh P. Pat Welsh's Southern California Organic Gardening. San Francisco: Chronicle Books; 2010.

19. Caser M, Ruffoni B, Scariot V. Screening for drought tolerance in Salvia spp. and Helichrysum petiolare: A way to select low maintenance ornamental plants. Acta Hortic 2012;953:239-46.

20. Delivering Alien Invasive Species Inventories for European (DAISIE); 2019. Available from: http://www.europe-aliens.org. [Last accessed on 2019 Mar 11]

21. Hendy J. 30-Minute Gardening: Creative Solutions, Tips and Tricks for a Great Garden Super-Fast! London: Dorling Kindersley Ltd.; 2012.

22. Randall RP. A Global Compendium of Weeds. Western Australia: Department of Agriculture and Food; 2012.

23. Mouriño J, Fagúndez J, Bernárdez G. Distribution and Invasiveness of the Alien Plant Helichrysum petiolare Hilliard, BL Burtt (Asteraceae) in Northwest Iberian Peninsula. Pontevedra: NEOBIOTA $7^{\text {th }}$ European Conference on Biological Invasions, September 2012; 2012.

24. Boyce RL. Invasive shrubs and forest tree regeneration. J Sustain For 2009;28:152-217.

25. Anderberg AA. Taxonomy and phylogeny of the tribe gnaphalieae (asteraceae). Opera Bot 1991;104:1-195.

26. Hickman JC. The Jepson Manual: Higher Plants of California. Berkeley: University of California Press; 1993.

27. Webb CJ, Sykes WR, Garnock-Jones PJ, Brownsey PJ. Checklist of dicotyledons, gymnosperms, and pteridophytes naturalised or casual in New Zealand: Additional records 1988-1993. New Zealand J Bot 1995;33:151-82.

28. Anderson LW, Di Tomaso L, Howald A, Randall J, Rejmanek M, Chairman JS. Exotic Pest Plants of Greatest Ecological Concern in California. California: California Exotic Plant Pest Council Special
Publication; 1996

29. Zimmermann HG, Klein H. The use of biological control agents for the control of plant invaders and the importance of partnerships. In: Preston G, Brown G, Van Wyk E, editors. Proceedings of the Best Management Practices Symposium. Cape Town: The Working for Water Program; 2000. p. 130-8.

30. Prunera-Olivé J, Galbany-Casals $M$, Cremades J, Fagúndez J. A new hybrid between two alien Helichrysum species (compositae, gnaphalieae) from NW Spain. Biol Invasions 2019;21:1481-90.

31. de Almeida JD, Freitas H. Exotic naturalized flora of continental Portugal: A reassessment. Bot Complut 2006;30:117-30

32. Howell JT. Marin Flora: Manual of the Vascular Plants and Ferns of Marin County, California. Berkeley: University of California Press; 1970.

33. Smith GL, Wheeler CR. A Flora of the Vascular Plants of Mendocino County. San Francisco: University of San Francisco; 1992.

34. Van Wyk BE, Oudtshoorn BV, Gericke N. Medicinal Plants of South Africa. Pretoria: Briza Publications; 2013.

35. Watt JM, Breyer-Brandwijk MG. The Medicinal and Poisonous Plants of Southern and Eastern Africa. Edinburgh: E and S Livingstone; 1962.

36. Hutchings A, Johnson CT. Glimpses of a xhosa herbal. Veld Flora 1986;72:59-62.

37. Mabogo DE. The Ethnobotany of the Vhavenda. MSc Dissertation. Pretoria: University of Pretoria; 1990.

38. Pujol J. NaturAfrica: The Herbalist Handbook, African Flora, Medicinal Plants. Durban: Jean Pujol Natural Healers Foundation; 1990.

39. Roberts M. Indigenous Healing Plants. Johannesburg: Southern Book Publishers; 1990.

40. Hutchings A, van Staden J. Plants used for stress-related ailments in traditional zulu, xhosa and sotho medicine. Part 1: Plants used for headaches. J Ethnopharmacol 1994;43:89-124.

41. Bhat RB, Jacobs TV. Traditional herbal medicine in Transkei. J Ethnopharmacol 1995;48:7-12.

42. Hutchings A, Scott AH, Lewis G, Cunningham AB. Zulu Medicinal Plants: An Inventory. Pietermaritzburg: University of Natal Press; 1996.

43. Jäger AK, Hutchings A, van Staden J. Screening of zulu medicinal plants for prostaglandin-synthesis inhibitors. J Ethnopharmacol 1996:52:95-100.

44. Arnold TH, Prentice CA, Hawker LC, Snyman EE, Tomalin M, Crouch NR, et al. Medicinal and Magical Plants of Southern Africa: An Annotated Checklist. Pretoria: National Botanical Institute; 2002.

45. Cocks M, Dold AP. Cultural significance of biodiversity: The role of medicinal plants in urban African cultural practices in the Eastern Cape, South Africa. J Ethnobiol 2006;26:60-81.

46. Van Wyk BE, Gericke N. Peoples' Plants: A Guide to Useful Plants of Southern Africa. Pretoria: Briza Publications; 2007.

47. van Wyk BE. A review of khoi-san and cape Dutch medical ethnobotany. J Ethnopharmacol 2008;119:331-41.

48. Aston Philander L. An ethnobotany of Western Cape rasta bush medicine. J Ethnopharmacol 2011;138:578-94

49. Bhat RB. Plants of xhosa people in the Transkei region of Eastern Cape (South Africa) with major pharmacological and therapeutic properties. J Med Plants Res 2013;7:1474-80.

50. Bhat RB. Medicinal plants and traditional practices of xhosa people in the Transkei region of Eastern Cape, South Africa. Indian J Tradit Knowl 2014;13:292-8.

51. Mabona U, Van Vuuren SF. Southern African medicinal plants used to treat skin diseases. S Afr J Bot 2013;87:175-93.

52. Afolayan AJ, Grierson DS, Mbeng WO. Ethnobotanical survey of medicinal plants used in the management of skin disorders among the xhosa communities of the Amathole district, Eastern Cape, South Africa. J Ethnopharmacol 2014;153:220-32.

53. Lall N, Kishore N. Are plants used for skin care in South Africa fully explored? J Ethnopharmacol 2014;153:61-84

54. Sewani-Rusike CR, Mammen M. Medicinal plants used as home remedies: A family survey by first year medical students. Afr J Tradit Complement Altern Med 2014;11:67-72.

55. Wintola OA, Afolayan AJ. An inventory of indigenous plants used as anthelmintics in Amathole district Municipality of the Eastern Cape province, South Africa. Afr J Tradit Complement Altern Med 2014;12:112-21

56. Maroyi A. Diversity of use and local knowledge of wild and cultivated plants in the Eastern Cape province, South Africa. J Ethnobiol Ethnomed 2017;13:43.

57. Van Wyk BE, Gorelik B. The history and ethnobotany of Cape herbal teas. S Afr J Bot 2017;110:18-38. 
58. Semenya SS, Maroyi A. Data on medicinal plants used to treat respiratory infections and related symptoms in South Africa. Data Brief 2018;21:419-23

59. Maroyi A. Phytochemical and ethnopharmacological review of Heteropyxis natalensis. Asian J Pharm Clin Res 2019;12:8-15.

60. Maroyi A. Lannea schimperi: Review of its botany, medicinal uses, phytochemistry and biological activities. Asian J Pharm Clin Res 2019;12:31-6.

61. Loundou PM. Medicinal Plant Trade and Opportunities for Sustainable Management in the Cape Peninsula, South Africa. MSc Dissertation. Cape Town: University of Stellenbosch; 2008.

62. Scott G, Springfield EP, Coldrey N. A pharmacognostical study of 26 South African plant species used as traditional medicines. Pharm Biol 2004;42:186-213.

63. Giovanelli S, De Leo M, Cervelli C, Ruffoni B, Ciccarelli D, Pistelli L. Essential oil composition and volatile profile of seven Helichrysum species grown in Italy. Chem Biodivers 2018;15:e1800545.

64. Popoola OK. Chemical and Biological Characterization of South African Helichrysum species. PhD Thesis. Cape Town: University of the Western Cape; 2013

65. Erasto P, Adebola P, Grierson D, Afolayan AJ. An ethnobotanical study of plants used for the treatment of diabetes in the Eastern Cape province, South Africa. Afr J Biotechnol 2005;4:1458-60.

66. Mahop MT, Mayet M. En route to biopiracy? Ethnobotanical research on anti diabetic medicinal plants in the Eastern Cape province, South
Africa. Afr J Biotechnol 2007;6:2945-52.

67. Mudumbi JB, Ntwampe SK, Mekuto L, Matsha T, Itoba-Tombo EF. The role of pollutants in Type 2 diabetes mellitus (T2DM) and their prospective impact on phytomedicinal treatment strategies. Environ Monit Assess 2018;190:262

68. Sabiu S, Madende M, Ajao AA, Ogundeji OA, Lekena N, Alayande KA. The scope of phytotherapy in Southern African antidiabetic healthcare. Trans R Soc S Afr 2019;74:1-18.

69. Lourens AC, Reddy D, Başer KH, Viljoen AM, Van Vuuren SF. In vitro biological activity and essential oil composition of four indigenous South African Helichrysum species. J Ethnopharmacol 2004;95:253-8.

70. Reddy D. The Phytochemistry and Antimicrobial Activity of Selected Indigenous Helichrysum species. MSc Dissertation. Johannesburg: University of the Witwatersrand; 2007.

71. Ras AM. Essential oil yield and composition of three Helichrysum species occurring in the Eastern Cape province of South Africa. S Afr J Bot 2013;86:181.

72. Lourens AC, Van Vuuren SF, Viljoen AM, Davids H, Van Heerden FR. Antimicrobial activity and in vitro cytotoxicity of selected South African Helichrysum species. S Afr J Bot 2011;77:229-35.

73. Sonka L. Exploring Anti-Tyrosinase Bioactive Compounds from the Cape flora. MSc Dissertation. Cape Town: University of the Western Cape; 2017.

74. Makhuvele R, Matshoga RG, Antonissen R, Pieters L, Verschaeve L, Elgorashi EE. Genotoxicity and antigenotoxicity of selected South African indigenous plants. S Afr J Bot 2018;114:89-99. 